Fikrah: Jurnal Ilmu Aqidah dan Studi Keagamaan

issn 2354-6147 eissn 2476-9649

Tersedia online di: journal.stainkudus.ac.id/index.php/Fikrah

DOI: http://dx.doi.org/10.21043/fikrah.v4i2.1884

\title{
Hubungan Antara Tipe Kepribadian Dengan Orientasi Religiusitas
}

\author{
Rini Risnawita Suminta \\ STAIN Kediri \\ risnawita_g@yahoo.com
}

\begin{abstract}
Abstrak
Tujuan dari penelitian ini adalah untuk mengetahui hubungan antara lima kepribadian besar dan orientasi keagamaan. Subyek penelitian ini adalah siswa program psikologi Islam, Departemen Ushuluddin, Sekolah Tinggi Agama Islam Negeri Kediri. Sampel $(\mathrm{N}=99)$ yang dikumpulkan melalui simple random sampling, dan mengisi angket dalam bentuk skala. Adapun skala yang digunakan adalah skala kepribadian big five dan orentasi religiusitas. Analisis data dalam penelitian ini dilakukan dengan menggunakan teknik korelasi produk moment dengan bantuan komputer program SPSS. Hasil penelitian menunjukkan bahwa ada hubungan positif yang signifikan antara kepribadian extraversion, openness to experience dan agreeableness dengan orientasi religius secara intrinsik dan sebaliknya ada hubungan negative yang signifikan antara kepribadian neurotisisme dan conscientiousness dengan orientasi religius secara intrinsik.
\end{abstract}

Kata kunci: Kepribadian big five. kepribadian extraversion, kepribadian neurotisisme, orentasi religiusitas 


\begin{abstract}
The aim of the present study was to determine the relationship between a big five personality and religious orientation. The subjects of this study were students of Islamic psychology program, Department of Ushuluddin, State College of Islamic Religion, Kediri. Samples $(N=99)$ were collected through a simple random sampling, and completed a questionnaire in the form of a scale. The instrument in this research had been applied by the big five personality scale and religious orientation scala. The analysis for this research used the Product Moment Analizing for Correlation between the variables with SPSS program. The results of the study showed that there was a positive significant relationship between extraversion, openness to experience, agreeableness and intrinsic religious orientation. In contrast, there was a negative significant relationship between neuroticism, conscientiousness and intrinsic religious orientation.
\end{abstract}

Keywords: Big five personality, Extraversion personality, neuroticism personality, religious orientation

\title{
Pendahuluan
}

"If we ask what psychology has contributed to our understanding of the religious nature of man, the answer is, "Less than we might wish." - Allport (John, Robins \& Pervin, 2008, hal. 649).

Psikologi kepribadian telah berdiri lama, dan telah mempunyai jalinan kuat dengan studi ilmiah tentang agama. Di satu sisi, beberapa pelopor yang paling penting psikologi kepribadian, termasuk Galton, Freud, Jung, Allport, dan McClelland, melihat fenomena agama sebagai topik yang menarik dan berharga pada penelitian ilmiah. Di sisi lain, bahkan selama era Allport, peneliti kepribadian terutama memberikan perhatian yang lebih terhadap tema religiusitas (McCullough, Tsang \& Briaon, 2003, hal. 980).

Religiusitas merupakan sebuah konsep yang luas dan cenderung sulit untuk dijelaskan secara definitif. Penjelasannya cenderung berada dalam keterkaitannya dengan istilah "agama". Memang tidak bisa dipungkiri bahwa antara "religiusitas" dan "agama" memiliki keterkaitan yang erat secara etimologis karena keduanya berasal dari bahasa Latin yang sama, religio atau religare, yang berarti mengumpulkan atau mengikat (Kahmad, 2002, hal. 13).

Menurut Manaf (1994, hal. 1), kata agama dalam bahasa Indonesia sama dengan "diin"(dari bahasa Arab) dalam bahasa Eropa disebut "religi", religion (bahasa Inggris), la religion (bahasa Perancis), the religie (bahasa Belanda), die religion, (bahasa Jerman). Kata "diin" dalam bahasa Semit berarti undang-undang (hukum), sedang kata diin dalam bahasa Arab berarti menguasai, menundukkan, patuh, hutang, balasan, kebiasaan. 
Anshori dalam Ghufron \& Risnawita (2010, hal. 167) membedakan antara istilah religi atau agama dengan religiusitas. Jika agama menunjuk pada aspek-aspek formal yang berkaitan dengan aturan dan kewajiban, maka religiusitas menunjuk pada aspek religi yang telah dihayati oleh seseorang dalam hati. Religiusitas sebagai keberagamaan karena adanya internalisasi agama tersebut ke dalam diri seseorang.

Agama adalah hubungan antara makhluk dengan Khalik (Tuhan) yang berwujud ibadah yang dilakukan dalam sikap kesehariaannya. Arti agama secara detail bahwa agama sebagai suatu sistem credo (tata keyakinan) atas adanya Yang Maha Mutlak dan suatu sistem norma (tata kaidah) yang mengatur hubungan manusia dengan sesama manusia dan dengan alam sekitarnya, sesuai dengan tata keimanan dan tata peribadatan tersebut (Ghufron \& Risnawita, 2010, hal. 167).

Menurut Rakhmat (2004, hal. 50-51), religiusitas adalah suatu keadaan yang ada dalam diri individu yang mendorongnya untuk bertingkah laku sesuai dengan kadar ketaatannya terhadap agama.

Pargament dalam Ghufron \& Risnawita (2015, hal. 58) mendefinisikan agama dalam arti luas dan multidimensi termasuk ekspresi keagamaan institusional, seperti dogma dan ritual, dan ekspresi keagamaan, seperti perasaan spiritualitas, keyakinan tentang yang suci, dan agama adalah praktek.

Dari berbagai pendapat di atas dapat ditarik kesimpulan bahwa agama menunjuk pada tingkat keterikatan individu terhadap agamanya. Hal ini menunjukkan bahwa individu telah menghayati dan menginternalisasikan ajaran agamanya sehingga berpengaruh dalam segala tindakan dan pandangan hidupnya.

Allport \& Ross yang dikutip oleh Mawani (2001, hal. 16) mengidentifikasi bahwa ada dua dimensi dasar religiusitas, yaitu ekstrinsik dan intrinsik. Mereka berdua menafsirkan religiusitas ekstrinsik sebagai pandangan melayani diri sendiri dan menyediakan kenyamanan dalam keselamatan. Dalam dimensi ekstrinsik ini yaitu ketika individu menggunakan agama untuk tujuan pribadi, seperti status sosial, kepentingan pembenaran diri, dan sering selektif dalam membentuk keyakinan agar sesuai dengan tujuan sendiri. Dengan demikian, orientasi religius ekstrinsik adalah cara pandang seseorang dalam beragama yang menggunakan agama sebagai alat untuk mencapai tujuan-tujuan yang berpusat pada dirinya sendiri (Batson \& Schoenrade, 1991, hal. 416). Menurut Darviri, Galanakis, Avgoustidis, Pateraki \& Vasdekis (2014, hal. 1558), pada orientasi religius ekstrinsik penekanan diberikan pada penampilan luar dari agama, aspek-aspek yang dapat diraba, berupa ritual dan terlembaga dari agama yang banyak dianggap sebagai tanda ketaatan dalam kebudayaan.

Orang-orang yang berorientasi religius secara ekstrinsik mempunyai kecenderungan besar menggunakan religiusitasnya untuk mencapai tujuan pribadi mereka, dan bukanlah berupa motif pengarah atau motif pemandu, tetapi lebih ke motif pelayanan motif-motif yang lain. 
Menurut Darvyri et al. (2014, hal. 1558) seseorang dengan religiusitas intrinsik adalah orang yang menginternalisasi keyakinan agamanya secara total, bukan sekedar kehadiran di tempat ibadah. Orientasi religius intrinsik merupakan cara beragama yang memikirkan komitmen terhadap agama dengan seksama dan memperlakukan komitmen tersebut dengan sungguh-sungguh sebagai tujuan akhir. Pada individu intrinsik, ajaran agama diinternalisasikan dan diikuti secara penuh. karena Agama berfungsi sebagai framework dalam menjalani kehidupan. Lebih jelasnya seorang yang berorientasi religius secara intrinsik adalah seseorang yang berusaha sungguhsungguh untuk menghayati ajaran dan mengikuti petunjuknya secara penuh.

Seorang muslim yang orientasi religius secara intrinsik, dengan kesadaran penuh melaksanakan ibadah dan berprilaku sesuai tuntunan agama yang timbul dari dalam dirinya, bukan karena ada dorongan dari luar, status sosial, atau ingin mencapai pengakuan dari orang lain.

Ada beberapa faktor yang menentukan orentasi religiusitas sesorang, di antaranya adalah kepribadian. Pada dasarnya, kepribadian memiliki banyak definisi dimana istilah kepribadian digunakan untuk mencakup segala sesuatu mengenai individu. Para teoretikus biasanya mendaftar konsep-konsep yang dianggap yang dianggap sangat penting untuk menggambarkan individu tersebut. Sejumah teoritikus memilih memberi tekanan pada fungsi kepribadian dalam menjembatani atau mengatur penyesuaian diri individu, walau tidak semua definisi subtantif dari kepribadian tersebut dapat diberlakukan secara (McCullough, Tsang \& Brion 2003, hal. 980).

Suryabrata dalam Ghufron (2011, hal. 122) menjelaskan bahwa kepribadian merupakan suatu kebulatan dari aspek-aspek jasmaniah dan rokhaniah, yang bersifat dinamis dalam hubungannya dengan lingkungan, berkembang dan dipengaruhi oleh faktor yang berasal dari dalam dan dari luar individu, serta bersifat khas di mana kepribadian masing-masing individu berbeda antara individu yang satu dengan yang lainnya.

Jung dalam Daryl (1987, hal. 12) mendefinisikan kepribadian melalui istilah psyche. Psyche merupakan totalitas segala peristiwa psikis baik yang disadari maupun yang tidak disadari. Menurut Jung, jiwa manusia terdiri dari dua alam, yakni alam sadar dan alam tak sadar, dimana keduanya saling mengisi serta berhubungan secara kompensatoris. Fungsi dari hubungan tersebut adalah untuk penyesuian diri, dimana alam sadar berfungsi untuk penyesuaian terhadap dunia luar, sedangkan alam tak sadar untuk penyesuaian dengan dunia dalam. Alport dalam Abdullah, Omar \& Panatik (2016, hal. 177) memberikan definisi kepribadian adalah dinamika organisasi yang terdapat dalam diri individu yang merupakan sistem psychophycal yang menentukan individu tesebut dalam melakukan penyesuaian diri secara unik terhadap lingkungannya.

Dari definisi-definisi di atas, maka kepribadian menurut peneliti merupakan komponen dalam diri individu yang berupa kesadaran maupun ketidaksadaran yang saling berhubungan antara satu dengan yang lainnya untuk saling mengisi 
yang membantu individu tersebut dalam melakukan penyesuaian diri terhadap lingkungannya secara khas dan termanifestasikan dalam pikiran, perasaan dan perilaku.

Mengenal teori kepribadian, pada dasarnya banyak teori yang telah dikembangkan. Dari sekian banyak teori yang telah banyak memberi kontribusi dalam pengembangan ilmu psikologi, terdapat teori yang mengemukakan adanya lima bentuk tipe kepribadian yang dikembangkan oleh McCrae dan Costa yang dikenal dengan Big Five Personality (McCullough, Tsang \& Brion 2003, hal 981). Dalam teori tersebut terdapat lima bentuk kepribadian yang mendasari perilaku individu, yang meliputi kepribadian neuroticism, kepribadian extrovert, kepribadian agreeableness, kepribadian conscientiousness dan kepribadian open to experience.

Kepribadian neuroticism disebut juga dengan istilah Negative Emotionality. Tipe kepribadian ini merupakan hal yang bersifat kontradiktif dari hal yang menyangkut kestabilan emosi dan identik dengan segala bentuk emosi yang negatif seperti munculnya perasaan cemas, sedih, tegang dan gugup (Ghufron, 2011, hal. 136).

Kepribadian extrovert menurut Bakker Van Der Zee, Lewig \& Dollard (2006, hal. 34) tipe kepribadian extrovert merupakan dimensi yang menyangkut hubungannya dengan perilaku suatu individu khususnya dalam hal kemampuan mereka dalam menjalin hubungan dengan dunia luarnya. Karakteistik kepribadian ini dapat dilihat melalui luasnya hubungan suatu individu dengan lingkungan sekitar mereka dan sejauhmana kemampuan mereka dalam menjalin hubungan dengan individu yang lain khususnya ketika berada di lingkungan yang baru.

Pada pribadi ekstrovert menurut Bakker, dkk (2006, hal. 34) akan ditunjukkan melalui sikapnya yang hangat, ramah, penuh kasih sayang, serta selalu menunjukkan keakraban terutama pada orang yang telah ia kenal. Mereka kerap memiliki ketertarikan yang tinggi dalam bergaul dan untuk bergabung dalam kelompokkelompok sosial. Individu dengan tipe kepribadian extrovert cenderung tegas dalam mengambil keputusan serta tidak segan-segan untuk menempatkan dirinya dalam posisi kepemimpinan. Mereka selalu menunjukkan sikap yang aktif terhadap perubahan keadaan dan selalu membutuhkan suasana yang mampu membuatnya gembira sehingga sikapnya cenderung periang terutama dalam mengapresiasikan emosi mereka. Adapun lawan dari tipe kepribadian ekstrovert adalah tipe kepribadian introvert.

Tipe kepribadian introvert ditunjukkan melalui rendahnya kemampuan individu dalam menjalin hubungan dengan lingkungan sosial mereka. Hal ini dapat dilihat melalui terbatasnya hubungan mereka dengan lingkungan di sekitarnya. Sikap dan perilaku mereka cenderung formal, pendiam dan tidak ramah. Dalam mengapresiasikan emosi pada kondisi yang bahagiapun ia akan tampak tenang dan menunjukkan ekspresi yang datar dan tidak berlebihan. Mereka jarang sekali menunjukkan ketertarikan pada aktifitas-aktifitas yang melibatkan kelompok dalam lingkungan sosial. Orang introvert memiliki sikap yang cenderung menyerah pada 
keadaaan dan tertinggal dalam mengikuti perkembangan keadaan (Ghufron, 2011, hal. 137).

Kepribadian agreeableness menurut Timothy (2000, hal. 752), mengidentifikasikannya dengan perilaku prososial di mana termasuk di dalamnya adalah perilaku yang selalu berorientasi pada altruisme, rendah hati dan kesabaran.

Kepribadian conscientiousness untuk mengidentifikasi sejauh mana individu memiliki sikap yang hati-hati dalalm mencapai suatu tujuan tertentu yang termanifestasikan dalam sikap dan perilaku mereka. Costa dan McCrae dalam Ghufron, 2011, hal. 140) mengkategorikan individu yang memiliki low conscientiousness sebagai kelompok flexible person, dan sebaliknya pada level yang tinggi (high conscientiousness) disebut sebagai focused person. Fleksibel person ditunjukkan melalui sikap individu yang selalu merasa tidak siap dalam segala hal. Dalam merespon perintah, flexible person akan cenderung menjalankan segala perintah yang ia terima secara tidak teratur, tidak terorganisir dengan baik dan tanpa metode yang jelas dan dapat diketahui melalui sikap dan perilakunya yang cenderung sembarangan dalam melaksanakan kewajibannya. Dalam motivasi untuk meraih prestasi, individu dengan low conscientiousness cenderung memiliki kebutuhan yang rendah dalam meraih prestasi. Mereka memiliki kebiasaan untuk menundanunda pekerjaan serta sering menunjukkan kekacauan atau kebingungan dalam menjalankan tugas yang dibebankan padanya. Dalam melakukan pertimbangan, individu dengan tingkat kehati-hatian rendah akan menunjukkan sikap dan perilaku yang lebih spontan dan terburu-buru dalam mengambil keputusan ketika dihadapkan dalam masalah yang perlu pertimbangan yang mendalam.

Sebaliknya pada focused person cenderung menampakkan sikap merasa mampu dalam melakukan segala sesuatu secara efektif. Mereka cenderung lebih rapi dan teratur sebagai bentuk perilaku yang selalu terorganisr dengan baik. Focused person lebih berhati-hati dalam menyelesaikan segala kewajiban yang dibebankan padanya dan dapat dipercaya serta lebih terkendali dalam menjalankan kewajiban guna mencapai kesuksesan yang diharapkan. Mereka lebih banyak memfokuskan segala tindakannya pada penyelesaian tugas secara keseluruhan. Dalam melakukan pertimbangan mereka selalu berfikir lebih mendalam dan hati-hati sebelum mengambil suatu keputusan (Ghufron, 2011, hal. 140).

Kepribadian openness to experience. Pada tipe iniadalah untukmengidentifikasi seberapa besar suatu individu itu memiliki ketertarikan terhadap bidang-bidang tertentu secara luas dan mendalam. Individu yang memiliki minat lebih terhadap sesuatu tertentu melebihi individu lainnya merupakan identifikasi bahwa individu tersebut memiliki level yang tinggi dalam tipe ini, dan sebaliknya bila suatu individu menunjukkan minat yang rendah maka identik dengan low openness to experience atau keterbukaan yang rendah terhadap pengalaman. Level yang rendah atau low openness disebut dengan preserver (O-) dan sebaliknya tingginya tingkat keterbukaan ini atau high openness disebut sebagai explorer (O+) (Ghufron, 2011, hal. 141) . 
McCrae \& Costa dalam Ghufron (2011, hal. 141) menjelaskan bahwa individu preserver akan cenderung lebih berfokus pada hal-hal yang sedang terjadi saat ini saja (here and now), tidak memiliki ketertarikan pada hal-hal yang menyangkut seni sebagai bentuk nilai estetika. Dalam hal perasaan, preserver lebih sering mengabaikan hal-hal yang menyangkut perasaan dan tindakannya lebih tertarik pada hal yang telah dikenalnya secara akrab saja. Mereka memiliki keterbatasan ide dibandingkan explorer dan bersifat kaku dalam memandang nilai-nilai kehidupan. Sebaliknya pada mereka yang explorer akan menunjukkan sikap yang imajinatif dan suka berangan-angan. Mereka lebih banyak melibatkan perasaan dan emosi yang mendalam dalam menilai segala hal dan memiliki ketertarikan pada hal yang sifatnya beragam dan condong untuk selalu mencoba hal yang dianggapnya baru. Ide yang mereka miliki lebih luas serta tidak jarang mengacu pada orang lain yang dianggapnya lebih pandai. Para explorer lebih terbuka untuk menguji kembali nilainilai kehidupan yang sudah ada sehingga lebih bersifat fleksibel.

Pada umumnya, individu eksplorer memiliki kemauan yang tinggi untuk menciptakan minat yang lebih luas terhadap segala aspek kehidupan, memiliki ketertarikan yang tinggi untuk mendalami hal yang baru yang diharapkan mendatangkan pengetahuan yang baru.

Saroglou (2002, hal. 15-25) menemukan hubungan negatif antara kepribadian ekstraversion dengan orentasi religiusitas yang intrinsik. Hal ini menunjukkan bahwa orang yang skor tinggi pada keterbukaan untuk pengalaman cenderung pengukuran mengalami religiusitas intrinsik. Kepribadian keterbukaan untuk mengalami hubungan negatif dengan fundamentalisme agama. Keterbukaan untuk mengalami kepribadian hubungan positif dengan jatuh tempo agama. Dalam model kepribadian extraversion, individu sangat extraverted menunjukkan religiusitas intrinsik yang lebih tinggi. Sedangkan kepribadian neurotik, individu yang mencetak tinggi pada tingkat neurotisisme mendapatkan skor rendah pada religiusitas intrinsik atau kedewasaan agama dan mendapatkan skor tinggi pada agama ekstrinsik. Oleh karena itu, tujuan dari penelitian ini adalah untuk mengetahui hubungan hubungan antara lima kepribadian besar dan toleransi beragama.

\section{Metode}

Responden

Subyek penelitian ini adalah siswa dari psikologi Islam, Departemen Ushuluddin, Negara Perguruan Tinggi Agama Islam Kediri. Sampel (N=99) dikumpulkan melalui simple random sampling. Rentang usia sampel penelitian wes antara 18 sampai 22 tahun.

\section{Instrumen penelitian}

Pengumpulan data yang digunakan dalam penelitian ini adalah angket dalam bentuk skala. Adapun instrumen yang dipergunakan dalam penelitian ini adalah skala orientasi religiusitas dan skala kepribadian big five. 


\section{Tehnik Analisis Data}

Analisis data dalam penelitian ini dilakukan dengan menggunakan teknik korelasi Pearson. Data dianalisis dengan SPSS.

\section{Hasil}

Sebelum dilakukan uji hipotesis, akan dipaparkan terlebih dahulu data deskriptif penelitian untuk tiap variabel. Deskripsi statistik data penelitian diringkas pada tabel 1 berikut:

Tabel 1. Deskripsi data penelitian

\section{Descriptive Statistics}

\begin{tabular}{llll}
\hline Variable & Mean & Std. Deviation & N \\
\hline Neuroticism & 11.080 & 2.333 & 99 \\
Extrovert & 11.202 & 3.252 & 99 \\
Agreeableness & 11.161 & 3.507 & 99 \\
Conscientiousness & 10.384 & 2.132 & 99 \\
Open to experience & 8.949 & 2.504 & 99 \\
Orentasi Religiositas & 5.9393 & 1.627 & 99 \\
\hline
\end{tabular}

Berdasarkan tabel 1 di atas diketahui untuk bahwa tipe kepribadian neuroticism mendapatkan skor rerata empiriknya sebesar 11.080, dengan nilai standar deviasi sebesar 2.333. Tipe kepribadian extrovert mendapatkan skor rerata empiriknya sebesar 11.202, dengan nilai standar deviasi sebesar 3.252. Tipe kepribadian agreeableness mendapatkan skor rerata empiriknya sebesar 11.161, dengan nilai standar deviasi sebesar 3.507. Tipe kepribadian conscientiousness mendapatkan skor rerata empiriknya sebesar 10.384, dengan nilai standar deviasi sebesar 2.132. Tipe kepribadian open to experience mendapatkan skor rerata empiriknya sebesar 8.949, dengan nilai standar deviasi sebesar 2.504. Semenatar variabel orentasi religiusitas mendapatkan skor rerata empiriknya sebesar 5.9393, dengan nilai standar deviasi sebesar 1.627 .

Setelah diketahui deskripsi masing-masing variabel kemudian dilakukan uji hipotesis hubungan antara tipe kepribadian dengan orentasi religiusita mahasiswa. Adapun hasil uji hipotesis diringkas pada tabel 2 berikut: 
Tabel 2: Hasil uji hipotesis

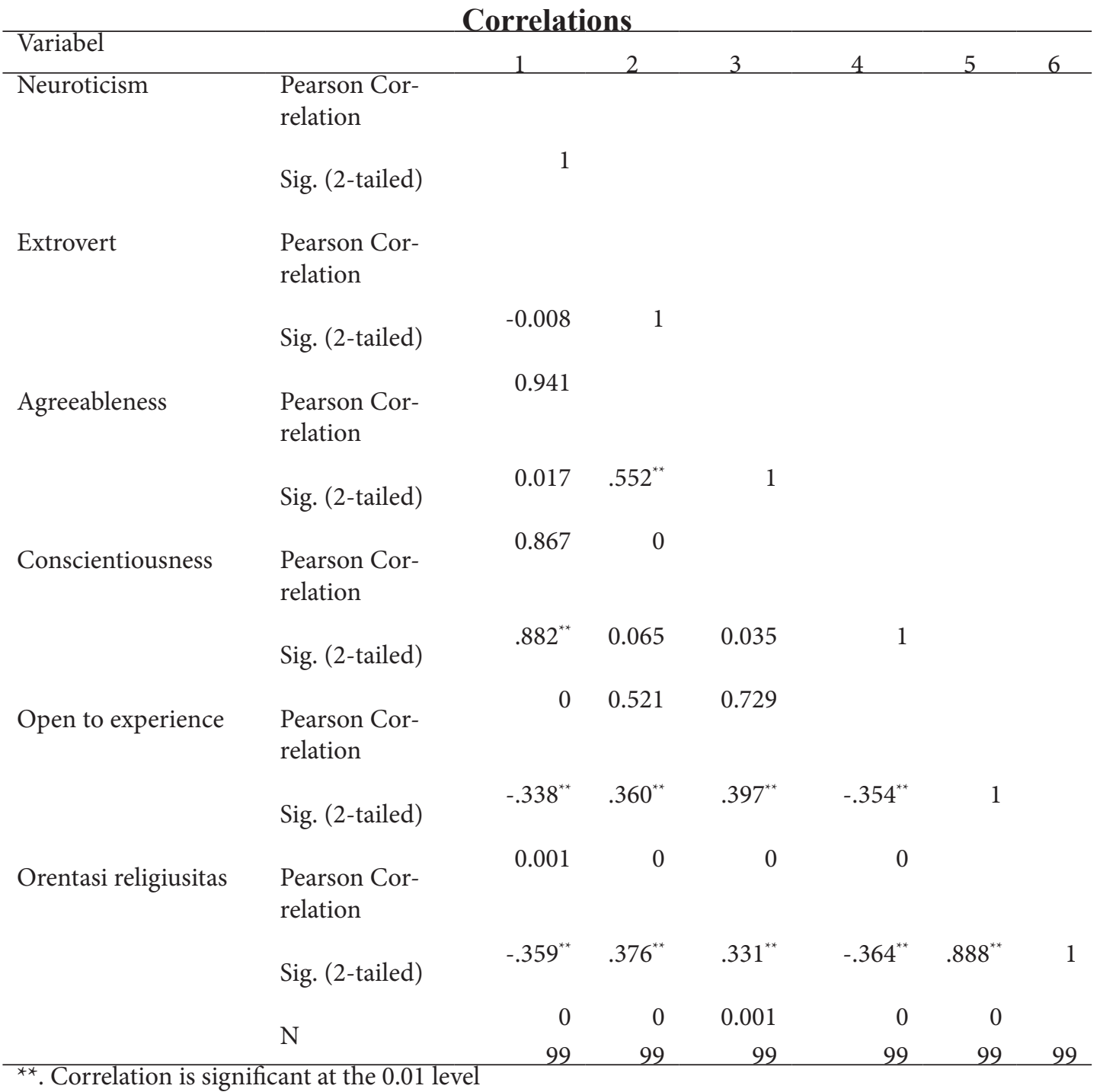

(2-tailed).

Berdasarkan hasil uji hipotesis diperoleh bahwa tipe kepribadian neuroticism mempunyai korelasi negatif dengan orentasi religiusitas sebesar $r=-0,359 ; p=0,000$, tipe kepribadian extrovert mempunyai korelasi positif dengan orentasi religiusitas sebesar $\mathrm{r}=0,376 ; \mathrm{p}=0,000$, tipe kepribadian agreeableness mempunyai korelasi positif dengan orentasi religiusitas sebesar $\mathrm{r}=0,331 ; \mathrm{p}=0,001$. tipe kepribadian conscientiousness mempunyai korelasi negatif dengan orentasi religiusitas sebesar $r=-0,364 ; p=0,000$, tipe kepribadian open to experience mempunyai korelasi yang positif dengan orentasi religiusitas sebesar $r=0,888 ; p=0,000$.

Berdasarkan hasil analisis di atas ditemukan bahwa hanya tipe kepribadian neuroticism dan tipe kepribadian conscientiousness yang mempunyai hubungan negatif dengan orentasi religiusitas. Artinya juga bahwa semakin individu mempunyai tipe kepribadian neuroticism dan tipe kepribadian conscientiousness, 
individu mempunyai kecenderungan mempunyai orentasi religiusitas yang eksternal. Sementara tipe kepribadian extrovert, agreeableness dan open to experience mempunyai hubungan positif dengan orentasi religiusitas. yang menandakan pula bahwa semakin individu mempunyai tipe kepribadian extrovert, agreeableness dan open to experience, individu kecenderungan mempunyai orentasi religiusitas yang internal.

\section{Diskusi}

Berdasarkan hasil penelitian menunjukkan bahwa ada hubungan yang signifikan antara dimensi kepribadian dengan orentasi religiusitas. Tipe kepribadian neurotisme dan tipe kepribadian conscientiousness memiliki korelasi negatif yang signifikan dengan orentasi religiusitas. Sementara tipe kepribadian extrovert, agreeableness dan open to experience berkorelasi positif dengan orentasi religiusitas.

Sebagaimana penjelasan sebelumnya bahwa Allport dan Ross membagi dua dimensi dasar religiusitas, yaitu ekstrinsik dan intrinsik. Religiusitas ekstrinsik berpandangan bahwa individu menggunakan agama untuk tujuan pribadi, seperti status sosial, kepentingan pembenaran diri, dan sering selektif dalam membentuk keyakinan agar sesuai dengan tujuan sendiri. Individu dalam beragama yang menggunakan agama sebagai alat untuk mencapai tujuan-tujuan yang berpusat pada dirinya sendiri.

Adapun individu dengan religiusitas intrinsik adalah orang yang menginternalisasi keyakinan agamanya secara total, bukan sekedar kehadiran di tempat ibadah. Orientasi religius intrinsik merupakan cara beragama yang memikirkan komitmen terhadap agama dengan seksama dan memperlakukan komitmen tersebut dengan sungguh-sungguh sebagai tujuan akhir (Batson \& Schoenrade, 1991, hal. 416). Pada individu intrinsik, ajaran agama diinternalisasikan dan diikuti secara penuh. karena Agama berfungsi sebagai framework dalam menjalani kehidupan. Lebih jelasnya seorang yang berorientasi religius secara intrinsik adalah seseorang yang berusaha sungguh-sungguh untuk menghayati ajaran dan mengikuti petunjuknya secara penuh.

Seorang muslim yang orientasi religius secara intrinsik, dengan kesadaran penuh melaksanakan ibadah dan berprilaku sesuai tuntunan agama yang timbul dari dalam dirinya, bukan karena ada dorongan dari luar, status sosial, atau ingin mencapai pengakuan dari orang lain.

Hasil penelitian ini menunjukkan bahwa tipe kepribadian neurotisme dan tipe kepribadian conscientiousness memiliki korelasi negatif yang signifikan dengan orentasi religiusitas secara internal. Tipe kepribadian neurotik merupakan tipe kepribadian dengan hal yang bersifat kontradiktif pada kestabilan emosi dan identik dengan segala bentuk emosi yang negatif seperti munculnya perasaan cemas, sedih, tegang dan gugup, sehingga pada posisi tertentu agama dijadikan untuk melayani diri sendiri dan menyediakan kenyamanan dalam keselamatan. 
Sementara pada kepribadian conscientiousness mengidentifikasi sejauh mana individu memiliki sikap yang hati-hati dalalm mencapai suatu tujuan tertentu yang termanifestasikan dalam sikap dan perilaku mereka. Seorang dengan kepribadian conscientiousness mempunyai sikap yang selalu merasa tidak siap dalam segala hal. Dalam merespon perintah, akan cenderung menjalankan segala perintah yang ia terima secara tidak teratur, tidak terorganisir dengan baik dan tanpa metode yang jelas dan dapat diketahui melalui sikap dan perilakunya yang cenderung sembarangan dalam melaksanakan kewajibannya. Memiliki kebiasaan untuk menundanunda pekerjaan serta sering menunjukkan kekacauan atau kebingungan dalam menjalankan tugas yang dibebankan padanya. Dalam melakukan pertimbangan, individu dengan tingkat kehati-hatian rendah akan menunjukkan sikap dan perilaku yang lebih spontan dan terburu-buru dalam mengambil keputusan ketika dihadapkan dalam masalah yang perlu pertimbangan yang mendalam menjadikan orentasi dalam beragama juga tidak ada kepastian, bahkan, agama seolah dijadikan untuk tujuan pribadi, seperti status sosial, kepentingan pembenaran diri, dan sering selektif dalam membentuk keyakinan agar sesuai dengan tujuan sendiri.

Hasil penelitian ini konsisten dengan penelitian sebelumnya tentang tipe kepribadian seseorang berkaitan dengan orientasi keagamaan. Seperti hasil penelitian Saroglou (2002, hal. 15-25) yang membuktikan bahwa tipe kepribadian neurotisisme berpengaruh negatif pada agama pada umumnya. Masih dari hasil penelitian Saroglou (2002, hal. 15-25) menemukan bahwa kepribadian neurotisisme positif mempengaruhi religiusitas ekstrinsik. Selain itu, neurotisme berkorelasi positif dengan fundamentalisme agama (Saroglou, 2002, hal. 15-25). Hasil penelitian Mijares \& Espinosa (2014, hal. 108) menemukan bahwa religiusitas berhubungan dengan tipe kepribadian agreeableness, conscientiousness, dan honesty.

Hasil penelitian ini juga menujukkan bahwa tipe kepribadian extrovert, agreeableness dan open to experience berkorelasi positif dengan orentasi religiusitas. Artinya bahwa semakin individu mempunyai tipe kepribadian extrovert, agreeableness dan open to experience, individu kecenderungan mempunyai orentasi religiusitas yang internal.

Adanya hubungan positif antara tipe kepribadian extrovert dengan orentasi religiusitas, dikarenakan tipe kepribadian extraversion mempunyai kecenderungan ramah saat berada di sekitar orang, dan menikmati kegembiraan dan stimulasi. Individu dengan tipe kepribadian extraversion yang tinggi cenderung tegas, aktif, banyak bicara, energik, optimis, dan toleransi sehingga pada individu dengan tipe ini menginternalisasi keyakinan agamanya secara total, bukan sekedar kehadiran di tempat ibadah.

Individu dengan kepribadian agreeableness cenderung mempunyai perilaku prososial di mana termasuk di dalamnya adalah perilaku yang selalu berorientasi pada altruisme, rendah hati dan kesabaran. Individu dengan tipe kepribadian ini selalu memandang individu lain sebagai orang yang jujur dan memiliki iktikad yang baik terhadapnya. Individu memiliki kerendahan hati, yang akan ditunjukkan 
dengan sikap dan perilaku yang sederhana dan memandang orang lain lebih mampu dari padanya. Individu selalu berterus terang terhadap lingkungan sekitarnya dan selalu berusaha untuk mendahulukan kepentingan orang lain di atas kepentingan diri sendiri. Pada pribadi ini cenderung memiliki kemauan yang besar dalam memberikan pertolongan pada orang lain dan tulus dalam melakukannya yang berkaitan ada perilaku berusaha sungguh-sungguh untuk menghayati ajaran dan mengikuti petunjuknya secara penuh.

Pada individu dengan kepribadian openness to experience cenderung memiliki ketertarikan terhadap bidang-bidang tertentu secara luas dan mendalam. Individu yang memiliki minat lebih terhadap sesuatu tertentu melebihi individu lainnya, keterbukaan yang tinggi terhadap pengalaman dan pada umumnya, individu memiliki kemauan yang tinggi untuk menciptakan minat yang lebih luas terhadap segala aspek kehidupan, memiliki ketertarikan yang tinggi untuk mendalami hal yang baru yang diharapkan mendatangkan pengetahuan yang baru. Dikarenakan mempunyai individu dengan tipe openness to experience terbuka terhadap pengalaman menjadikan orentasi beragamanya dengan mengedepankan komitmen terhadap agama dengan seksama dan memperlakukan komitmen tersebut dengan sungguh-sungguh sebagai tujuan akhir

Hasil penelitian ini memperkuat hasil penelitian sebelumnya seperti hasil penelitian Saroglou (2002, hal. 15-25) melakukan meta-analisis hubungan antara religiusitas dan lima tipe kepribadian. Tipe kepribadian extrovert dan open to experience mempunyai hubungan negatif dengan keberagamaan yang fundamental.

\section{Simpulan}

Berdasarkan hasil penelitian ini, maka dapat disimpulkan bahwa tipe kepribadian neuroticism mempunyai korelasi negatif dengan orentasi religiusitas, tipe kepribadian extrovert mempunyai korelasi positif dengan orentasi religiusitas, tipe kepribadian agreeableness mempunyai korelasi positif dengan orentasi religiusitas, tipe kepribadian conscientiousness mempunyai korelasi negatif dengan orentasi religiusitas dan tipe kepribadian open to experience mempunyai korelasi yang positif dengan orentasi religiusitas.

Berdasarkan hasil analisis di atas ditemukan bahwa hanya tipe kepribadian neuroticism dan tipe kepribadian conscientiousness yang mempunyai hubungan negatif dengan orentasi religiusitas. Artinya juga bahwa semakin individu mempunyai tipe kepribadian neuroticism dan tipe kepribadian conscientiousness, individu mempunyai kecenderungan mempunyai orentasi religiusitas yang eksternal. Sementara tipe kepribadian extrovert, agreeableness dan open to experience mempunyai hubungan positif dengan orentasi religiusitas. yang menandakan pula bahwa semakin individu mempunyai tipe kepribadian extrovert, agreeableness dan open to experience, individu kecenderungan mempunyai orentasi religiusitas yang internal. 


\section{Referensi}

Arnold, B. B., Karen, I., Van, D. Z., Kerry, A. L., \& Maureen, F. D. (2006). The Relationship Between the Big Five Personality Factors and Burnout: A Study Among Volunteer Counselors. The Journal of Social Psychology, 146(1), 31-50. doi: 10.3200/SOCP.146.1.31-50

Batson, C. D., \& Schoenrade, P. A. (1991a). Measuring religion as quest: 1) Validity concerns. Journal for the Scientific Study of Religion, 30(4), 416-429.

Darvyri, P. G., Avgoustidis, M. A. G., Pateraki, N., Vasdekis, S., \& Darviri, C. (2014). The Revised Intrinsic/Extrinsic Religious Orientation Scale in a Sample of At-tica's Inhabitants. Psychology, 5, 1557-1567. Diambil dhttp://dx.doi. org/10.4236/psych.2014.513166

Daryl, S. (1987). Personality Types: Jung's Model of Typology. Toronto: Inner City Books.

Ghufron, M. N. (2011). Psikologi. Kudus: Nora Media Enterprise.

Ghufron, M. N., \& Risnawita, R. (2010). Teori-Teori Psikologi. Yogyakarta: AR-RUZ Media.

Ghufron, M. N. \& Risnawita, R. (2015). Sejahtera secara spiritual dengan Pendidikan Agama. Dipresentasikan pada Acara Seminar Nasional Educational Wellbeing, Fakultas Psikologi UMK Kudus.

Iqra, A., Rozeyta, O., \& Panatik, S. A. (2016). A Literatur e Review on Personality, Creativity and Innovative Behavior. International Review of Management and Marketing, 6(1), 177-182.

John, O. P., Robins, R. W., \& Pervin, L. A. (2008). Handbook of personality: Theory and research. New York: Guilford Press.

Kahmad, D. (2002). Sosiologi Agama, Bandung: PT. Remaja Rosdakarya.

Manaf, M. A. (1994). Ilmu Perbandingan Agama. Jakarta: PT. Raja Grafindo Persada.

Mawani, A. (2001). Personality Type and Religious Orientation in the Religious and Life Satisfaction of Muslirns and Christians. A Thesis. University of Manitoba: Manitoba.

McCrae, R. R., \& Costa, P. T., Jr. (1999). A Five-Factor Theory of personality. Dalam L. A. Pervin \& O. P. John (Eds.), Handbook of personality: Theory and research (2nd ed., hal. 139-153). New York: Guilford Press.

McCullough, M. E., Tsang, J.A., \& Brion, S. (2003). Personality Traits in Adolescence as Predictors of Religiousness in Early Adulthood: Findings from the Terman Longitudinal Study. Personality and Social Psychology Bulletin, 29(8), 980-991. 
doi : 10.1177/0146167203253210

McCullough, M. E. \& Tsang, J. A. (2002) Personality Traits in Adolescence as Predictors of Religiousness In Early Adulthood: Findings from the Terman Longitudinal Study. Diambil dari http://www.psy.miami.edu/faculty/ mmccullough/Papers/Relig-Big\%20Five_2002_dr2.pdf

Mijares, S. A., \& Espinosa, A. C. D. (2014). Religiosity and Personality in a Mexican Sample. International Journal of Humanities and Social Science, 4(1), 108112.

Rakhmat, J. (2004). Psikologi Agama: Sebuah Pengantar. Bandung: Mizan.

Saroglou, V. (2002). Religion and the Five Factors of personality: a Meta-Analytic Review. Personality and Individual Differences, 32, 15-25.

Saroglou, V., Delpierre, V., \& Dernelle, R. (2004). Values and religiosity: A MetaAnalysis of Studies using Schwartz's Model. Personality and Individual Differences, 37, 721-734. 